\title{
Synthesis of crosslinked PVA/Chitosan hydrogels loaded EGF and evaluation in vitro characterization
}

\section{EGF yüklü çapraz bağlı PVA/Kitozan hidrojellerin sentezi ve in vitro karakterizasyonunun değerlendirilmesi}

\author{
Murat Doğan ${ }^{1}$, Ali Demir Sezer ${ }^{1 *}$
}

*Department of Pharmaceutical Biotechnology, Faculty of Pharmacy, Marmara University, İstanbul, Turke

Corresponding author: Ali Demir Sezer, PhD, Department of Pharmaceutical Biotechnology, Faculty of Pharmacy, Marmara University, İstanbul, Turkey

E-mail: adsezer@marmara.edu.tr

Received/Accepted: March 09, 2020 /May 11, 2020

Conflict of interest: There is not a conflict of interest.

\section{SUMMARY}

Objective: The aim of this study was to prepare different hydrogels using chitosan and PVA polymers and to evaluate the cytotoxicity of hydrogels through cell culture studies. In addition, FTIR spectrum measurements were aimed to determine the specific chemical groups and bonds in the structures of hydrogels and materials.

Method: In this study, different hydrogels were prepared and 3- (4,5dimethyl-2-thiazolyl) -2,5-diphenyl tetrazolium bromide (MTT) test was performed to evaluate the toxicity of hydrogels on mouse fibroblast cell line (L-929). In addition, specific chemical groups of materials and hydrogels used in hydrogels were determined via FTIR spectrum study.

Results: According to the MTT cytotoxicity results B1 $(94.20 \pm 1.30 \%)$ and D2 $(82.45 \pm 1.05 \%)$ formulations showed the greatest and lowest L-929 cell viability respectively. According to the results of the FTIR absorption spectrum, the aliphatic $\mathrm{C}=\mathrm{O}$ tension band of rh-EGF was observed at 1634 $\mathrm{cm}^{-1}$.

Conclusions: Results showed that chitosan-PVA hydrogels containing rEGF types were observed to increase mouse fibroblast cell viability. In the FTIR spectrum results, spectral bands showing specific chemical groups of chitosan, PVA, PEGylation agents, rh-EGF and C2 formulation were obtained.

Keywords: Hydrogel, cell viability, chitosan.

\author{
D Murat Doğan \\ Ali Demir Sezer
}

ORCID IDs of the authors: M.D. 0000-0003-2794-0177 A.D.S. 0000-0002-2678-8903

\section{ÖZET}

Amaç: Bu çalışmanın amacı, kitozan ve PVA polimerlerini kullanarak farklı hidrojelleri hazırlamak ve hücre kültürü çalıșmalarıyla hidrojellerin sitotoksisitelerini değerlendirmektir. Ayrıca hidrojellerin ve materyallerin yapılarında bulunan spesifik kimyasal grupları ve bağları belirlemek amacıyla FTIR spektrum ölçümleri yapılması amaçlanmıştır. Yöntem: Calıșmada farklı hidrojeller hazırlanarak hidrojellerin fare fibroblast hücreleri (L-929) üzerindeki toksisitesini değerlendirmek amacıyla 3-(4,5-dimetil-2-tiyazolil)-2,5-difenil tetrazolyum bromid (MTT) testi uygulanmıştır. Ayrıca FTIR spektrum çalıșmasıyla hidrojellerde kullanılan maddelerin ve hidrojelin spesifik kimyasal grupları belirlenmiștir. Bulgular: MTT sitotoksisite sonuçlarına göre B1 (\% 94.20 \pm 1.30) ve D2 (\% $82.45 \pm 1.05)$ formülasyonları sırasılyla en yüksek ve en düşük L-929 hücre canlılığını göstermiştir. FTIR absobsiyon spektrum sonuçlarına göre rh-EGF'e ait alifatik $\mathrm{C}=\mathrm{O}$ gerilim band1 $1634 \mathrm{~cm}^{-1}$ de gözlenmiştir. 
Sonuç: Sonuçlara göre, r-EGF çeşitlerini içeren kitozan-PVA hidrojellerin fare fibroblast hücrelerinin canlılığını artırdığı gözlenmiş̧tir. FTIR spektrum sonuçlarında kitozana, PVA'ya, PEGilasyon ajanlarına, rh-EGF'e ve C2 formülasyonuna ait spesifik kimyasal grupları gösteren bantlar elde edilmiştir.

Anahtar sözcükler: Hidrojel, hücre canlıllı̆ı, kitozan.

\section{INTRODUCTION}

Hydrogels have a three-dimensional network structure formed by cross-linking of hydrophilic molecules with covalent bonds or keeping them together with intramolecular interactions ${ }^{1}$. Hydrogels have significantly similar properties with living tissues and their biocompatibility ensures their applicability. Hydrogels can be used as a carrier for pharmaceuticals and other therapeutic molecules in pharmaceutical and biomedical engineering fields ${ }^{1,2}$. Natural and synthetic polymers are used in the preparation of hydrogel formulations ${ }^{2}$. Chitosan, is a natural polymer, widely used in the biomedical field due to its biodegradable, low immunogenicity, mucoadhesive, and nontoxicity properties ${ }^{3,4}$. Polyvinyl alcohol (PVA) is a hydrophilic synthetic polymer with a chemically inert structure. PVA is widely used in different industries such as food, biomedical and pharmaceutical industries thanks to its simple structures, adhesive properties, filmforming ability, biocompatibility, swelling abilities, and non-carcinogen properties ${ }^{3,5}$. EGF, is a polypeptide structured macromolecule, plays a crucial role in the wound healing process by accelerating epidermal cell regeneration and stimulating keratinocyte migration and cell proliferation $^{6,7}$. Although EGF has widely using areas, it has stability problems in the application site. Various modifications can be performed on the EGF in order to increase the stability of EGF and thus increase its efficiencies ${ }^{7,8}$. PEGylation plays an important role in these modifications. PEGylation of EGF promoted its biological activity, stability, and solubility properties ${ }^{9}$. There are many studies in literature related to the cell viability efficiency of hydrogels including chitosan and PVA. In this study, different hydrogels were prepared and it was aimed to assess their cell viability efficiency and indicate of specific chemical groups in the formulation and materials via spectrophotometric analysis.

\section{MATERIAL AND METHODS}

MMW chitosan (Sigma, code: 448877), HMW chitosan (Sigma, code: 419419), PVA (Sigma, code: P1763) used as polymers for hydrogel were purchased from Sigma-Aldrich (USA). rh-EGF (Sigma, code: E9644), metoksi PEG propionaldehyde (MW 5 kD, Sigma, JKA 3039), metoksi PEG propionaldehyde (MW $10 \mathrm{kD}$, Sigma, JKA 3033), were purchased Sigma Aldrich (USA). rm-EGF (Gibco, P01133) was obtained Gibco (New Zealand). Cell viability kit, (MTT), (Roche, 11465007001, Switzerland) were purchased from Roche. All materials used in these studies were in analytical grade.

\section{Synthesis of hydrogel formulations}

In the preparation of hydrogels, the study of Sezer et al was used ${ }^{10}$. Chitosan and PVA were used as polymer in the preparation of hydrogel formulations. The concentration of high molecular weight chitosan and medium molecular weight chitosan in the formulations was determined as $3 \%$ $(w / v)$. In addition, PVA was used in formulations with a concentration of $2 \%(\mathrm{w} / \mathrm{v})$. The volumetric rate of chitosan to PVA in each formulation was determined as $4: 1$. The chitosan was dissolved in a $1 \%(\mathrm{v} / \mathrm{v})$ acetic acid solution by stirring in a magnetic stirrer. PVA was also dissolved in the magnetic stirrer via both heating $\left(80{ }^{\circ} \mathrm{C}\right)$ and stirring. Sterile bi-distilled water was used as the solvent for the preparation of formulations. After PVA was completely dissolved rh-EGF or rm-EGF $(10 \mu \mathrm{g} / \mathrm{ml})$, PEGylated r-EGF types and crosslinking agent, glutaraldehyde (GA), was added to the PVA solution and stirring was continued for $1 \mathrm{~h}$. The dissolved PVA solution was added to the chitosan solution and stirred for $4 \mathrm{~h}$. The hydrogels were placed in universal bottles and stored at $4{ }^{\circ} \mathrm{C}$. The hydrogel formulations list was stated in Table 1. 
Table 1: The components of the hydrogel formulations.

\begin{tabular}{|c|c|c|c|c|}
\hline Codes & $\begin{array}{c}\text { Molecular } \\
\text { weight of } \\
\text { chitosan }\end{array}$ & $\begin{array}{c}\text { rh-EGF } \\
\text { or } \\
\text { rm- } \\
\text { EGF }\end{array}$ & $\begin{array}{c}\text { Different } \\
\text { molecular } \\
\text { weight of } \\
\text { mPEG } \\
\text { propionaldehye }\end{array}$ & $\begin{array}{c}\text { Glutaraldehye } \\
\text { concentration } \\
\text { (g/ml) }\end{array}$ \\
\hline A1 & MMW & rh-EGF & --- & 0.001 \\
\hline A2 & MMW & rm-EGF & --- & 0.001 \\
\hline B1 & MMW & rh-EGF & $5 \mathrm{kD}$ & 0.001 \\
\hline B2 & MMW & rh-EGF & $10 \mathrm{kD}$ & 0.001 \\
\hline C1 & MMW & rm-EGF & $5 \mathrm{kD}$ & 0.001 \\
\hline C2 & MMW & rm-EGF & $10 \mathrm{kD}$ & 0.001 \\
\hline D1 & MMW & --- & --- & 0.001 \\
\hline D2 & MMW & --- & --- & 0.002 \\
\hline E1 & HMW & rh-EGF & --- & 0.001 \\
\hline E2 & HMW & rm-EGF & --- & 0.001 \\
\hline F1 & HMW & rh-EGF & $5 \mathrm{kD}$ & 0.001 \\
\hline F2 & HMW & rh-EGF & $10 \mathrm{kD}$ & 0.001 \\
\hline H1 & HMW & rm-EGF & $5 \mathrm{kD}$ & 0.001 \\
\hline H2 & HMW & rm-EGF & $5 \mathrm{kD}$ & 0.002 \\
\hline K1 & MMW & ---- & --- & --- \\
\hline K2 & HMW & ---- & --- & --- \\
\hline *All hydrogel formulations contain PVA $(2 \%$ w/v). & & \\
\hline
\end{tabular}

\section{Infrared absorption spectroscopy (FTIR) study}

Fourier Transform Infrared Spectroscopy (FTIR) was used to indicate specific chemical groups in the formulation and materials ${ }^{4,5}$. The infrared spectrum studies of hydrogels were performed (Perkin Elmer 1600 FT-IR, England). Before starting the study, hydrogels were converted into lyophilized powder with a lyophilizer. Infrared spectrum measurements of chitosan, PVA, rh-EGF and mPEG propionaldehyde were performed with the same method.

\section{Cell culture}

The cell viability of hydrogels was tested against the mouse fibroblast (L-929) cell line. Cells were cultured in low glucose DMEM (Dulbecco's modified eagle's medium) containing $10 \%$ FBS (fetal bovine serum), $1 \%$ L-glutamine, $100 \mathrm{IU} / \mathrm{mL}$ penicillin and $10 \mathrm{mg} / \mathrm{mL}$ streptomycin in $25 \mathrm{~cm}^{2}$ polystyrene flasks ${ }^{11}$. The cells were kept at $37^{\circ} \mathrm{C}$ with $5 \% \mathrm{CO}_{2}$. The cells were passaged when they had reached $85-90 \%$ confluence.

\section{In vitro cytotoxicity assay}

In vitro cytotoxicity of hydrogel samples were determined by MTT cell viability assay on L-929 (ATCC ${ }^{\circledR}$ CRL-2648) cell line. The cells were seeded at a predetermined confluence per well in a 96-well plate and incubated overnight. The cells were then treated with hydrogel samples for $24 \mathrm{~h}$. After the incubation period, $10 \mu \mathrm{l}$ MTT labeling solution was added to each well. Then, the plate was incubated for $12 \mathrm{~h}$. After the incubation period $100 \mu \mathrm{l}$ of the sodium dodecyl sulfate (SDS) was added into each well and samples were incubated overnight. The spectrophotometrical absorbance of the samples were measured using a microplate ELISA reader (Epoch Biotech, USA). The wavelength to measure the absorbance of the formazan product was $550 \mathrm{~nm}$. The reference wavelength determined to be $690 \mathrm{~nm}^{11,12}$.

\section{Statistical analysis}

The results of the studies were statistically evaluated using one-way analysis of variance (ANOVA) followed by Newman-Keuls multiple comparisons test. $p<0.05$ was considered to be indicative of significance and the results were indicated as the mean and \pm standard deviation (SD).

\section{RESULTS and DISCUSSION}

\section{Evaluation of FTIR spectrum results}

The results of IR absorption spectroscopy of chitosan were shown in Figure 1 and Figure 2. Current FTIR spectrum results were quite similar 
to the studies of Vino et $a l^{4}$. According to the results, the characteristic bands of chitosan were $3358 \mathrm{~cm}^{-1}, 3351 \mathrm{~cm}^{-1}$, and $3288 \mathrm{~cm}^{-1}$ amine group $\mathrm{N}-\mathrm{H}$ symmetrical stretch bands and $3099 \mathrm{~cm}^{-1} \mathrm{O}-\mathrm{H}$ asymmetric stretch bands. The presence of $\mathrm{N}$ acetyl groups was confirmed by the bands at around $1645 \mathrm{~cm}^{-1}(\mathrm{C}=\mathrm{O}$ stretching of amide $\mathrm{I})$.
$1558 \mathrm{~cm}^{-1}$ second amide bond corresponded to $\mathrm{N}$ $\mathrm{H}$ bending of amide II. The $\mathrm{CH}_{2}$ bending and $\mathrm{CH}_{3}$ symmetrical deformation were confirmed by the presence of bands at $1412 \mathrm{~cm}^{-1}$ and $1375 \mathrm{~cm}^{-1}$, respectively. Similarly, to Song et al. study, the absorption band at $1153 \mathrm{~cm}^{-1}$ constituted to asymmetric stretching of the $\mathrm{C}-\mathrm{O}-\mathrm{C}$ bridge ${ }^{13}$.

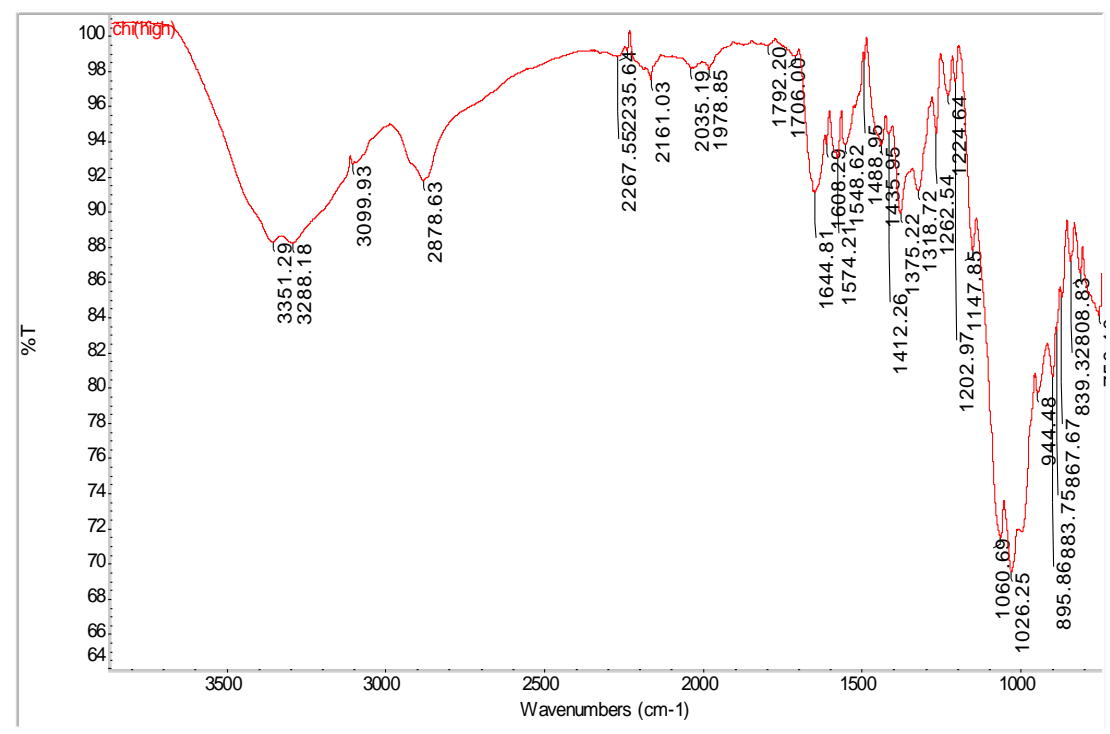

Figure 1: FTIR spectrum of chitosan (high molecular weight) with the characteristic signs.

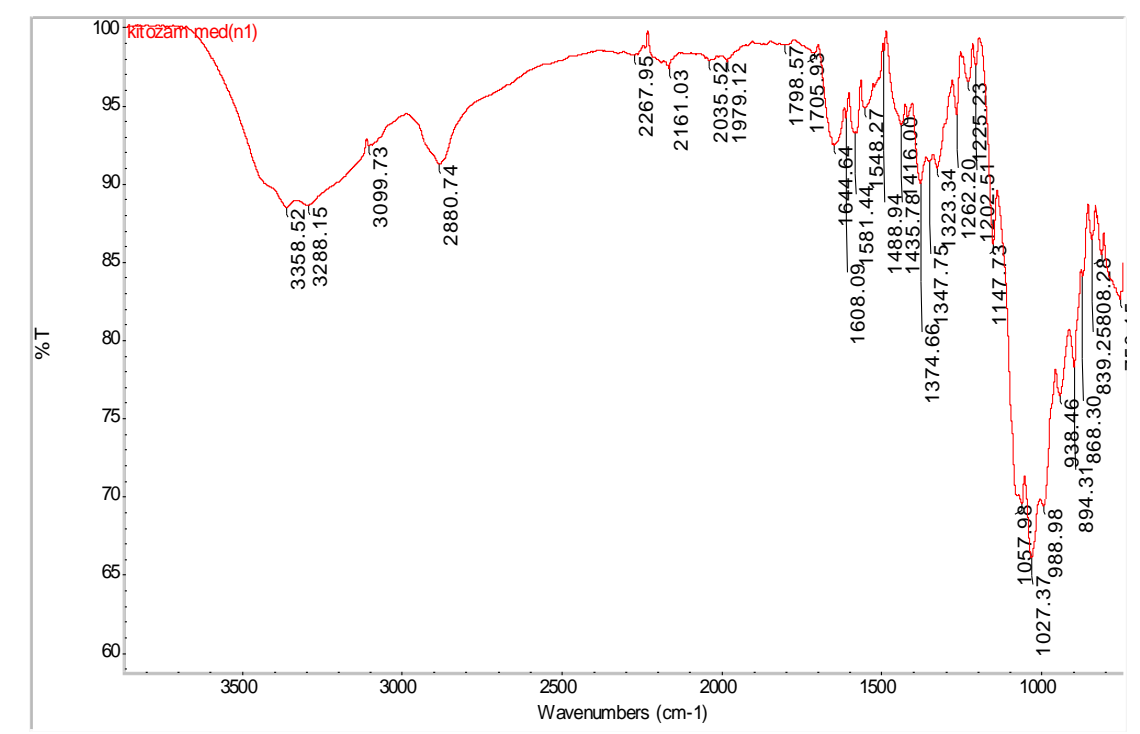

Figure 2: FTIR spectrum of chitosan (medium molecular weight) with the characteristic signs. 
The result of IR absorption spectroscopy of PVA was shown in Figure 3. Similarly, the FTIR spectrum study results of the Mansur et al. the large bands observed between $3500 \mathrm{~cm}^{-1}$ and 3100 $\mathrm{cm}^{-1}$ are linked to the $\mathrm{O}-\mathrm{H}$ streching band from the intramolecular and intermolecular hydrogen bonds ${ }^{5}$. According to the result, it was observed $2938 \mathrm{~cm}^{-1}$ and $2906 \mathrm{~cm}^{-1}$ bands refers to the $\mathrm{C}-\mathrm{H}$ stretching from alkyl groups.

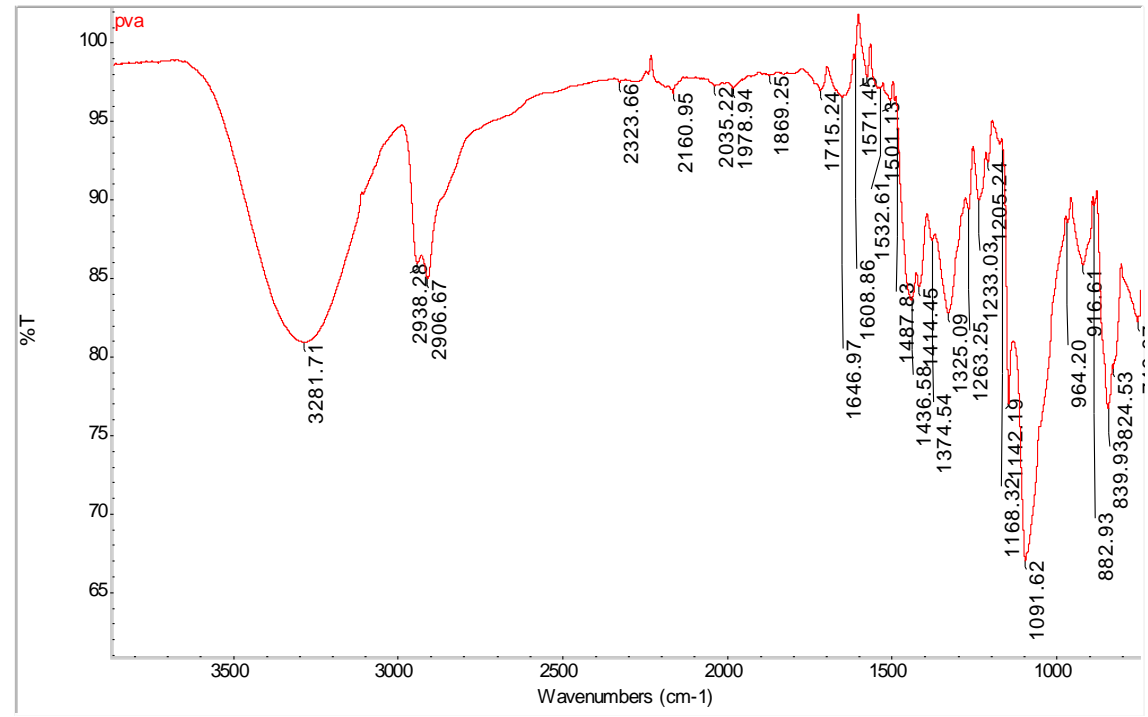

Figure 3: FTIR spectrum of PVA with the characteristic signs.

The FTIR absorption spectra of rh-EGF was shown in Figure 4. According to the results, aliphatic $\mathrm{C}=$ $\mathrm{O}$ tension band was observed at $1634 \mathrm{~cm}^{-1}$. In addition, tertiary $\mathrm{C}-\mathrm{N}$ tension band was indicated between $1230 \mathrm{~cm}^{-1}$ and $1030 \mathrm{~cm}^{-1}$. Aliphatic C-O tension band was observed at $1620 \mathrm{~cm}^{-1}$.

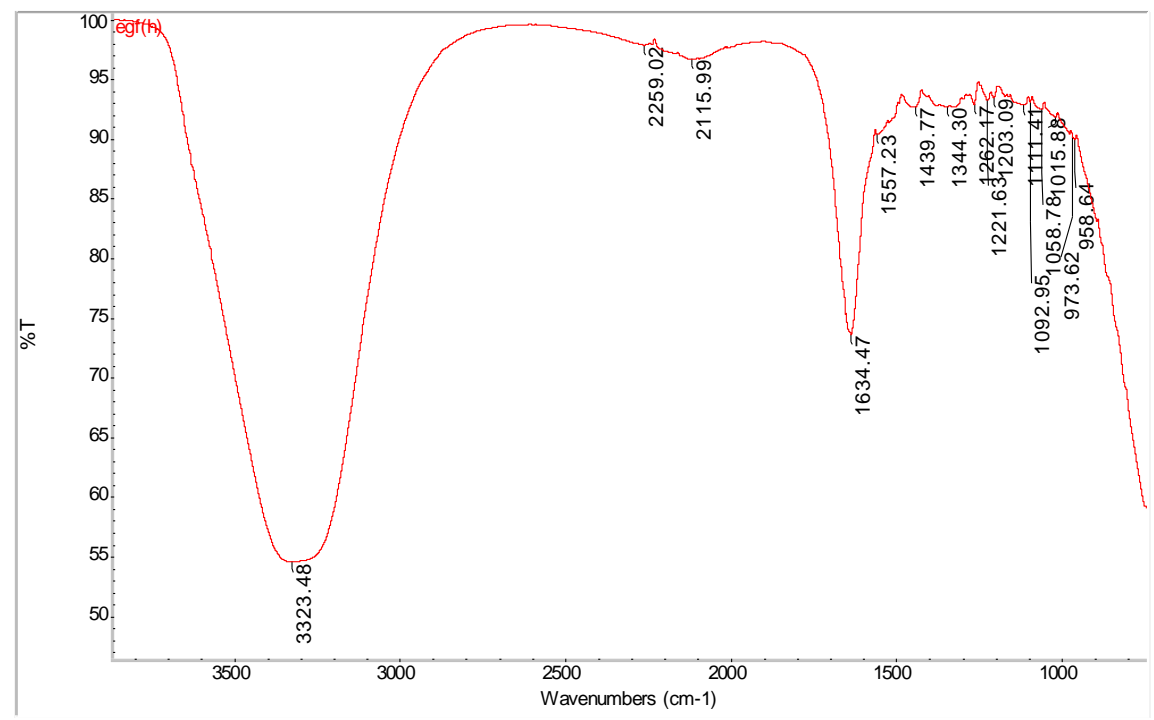

Figure 4: FTIR spectrum of rh-EGF with the characteristic signs. 
IR absorption spectrum result of mPEG propionaldehyde $10 \mathrm{kD}$ was shown in Figure 5. According to the results, aliphatic $\mathrm{C}-\mathrm{H}$ tension band was observed at $2882 \mathrm{~cm}^{-1}$. Moreover, the C$\mathrm{O}$ tension band was shown at $1096 \mathrm{~cm}^{-1}$. The bands between $1260 \mathrm{~cm}^{-1}$ and $1050 \mathrm{~cm}^{1}$ were linked to the $\mathrm{C}-\mathrm{O}-\mathrm{C}$ ether streching band refers to tertiary C-N tension. A tension band of $\mathrm{C}-\mathrm{O}$ was observed at $1620 \mathrm{~cm}^{-1}$.

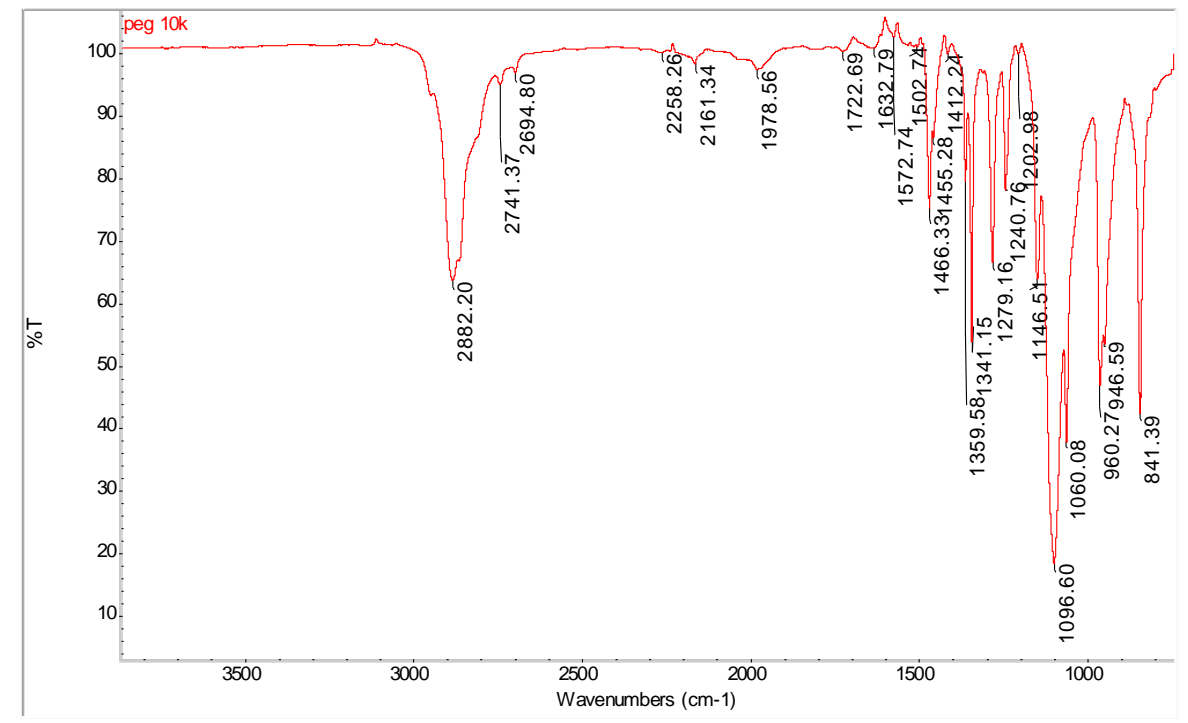

Figure 5: FTIR spectrum of mPEG propionaldehyde $10 \mathrm{kD}$ with the characteristic signs.

The $\mathrm{C} 2$ formulation was prepared using medium molecular weight chitosan, PVA and GA. It also contained rm-EGF and $\mathrm{mPEG}$ propionaldehyde 10 $\mathrm{kD}$. The result of IR absorption spectroscopy of $\mathrm{C} 2$ formulation was shown in Figure 6. According to the results, there was a wide band of $\mathrm{O}-\mathrm{H}$ stress that forms the intramolecular and intermolecular hydrogen bonds between $3500 \mathrm{~cm}^{-1}$ and $3000 \mathrm{~cm}^{-1}$. Aliphatic C-H tension band was observed at 2915 $\mathrm{cm}^{-1}$. Moreover, the presence of aliphatic $\mathrm{C}=\mathrm{O}$ tension band at $1608 \mathrm{~cm}^{-1}$ and $\mathrm{O}-\mathrm{C}$ tension band at $1065 \mathrm{~cm}^{-1}$ indicated that there was an ester group in the formulation.

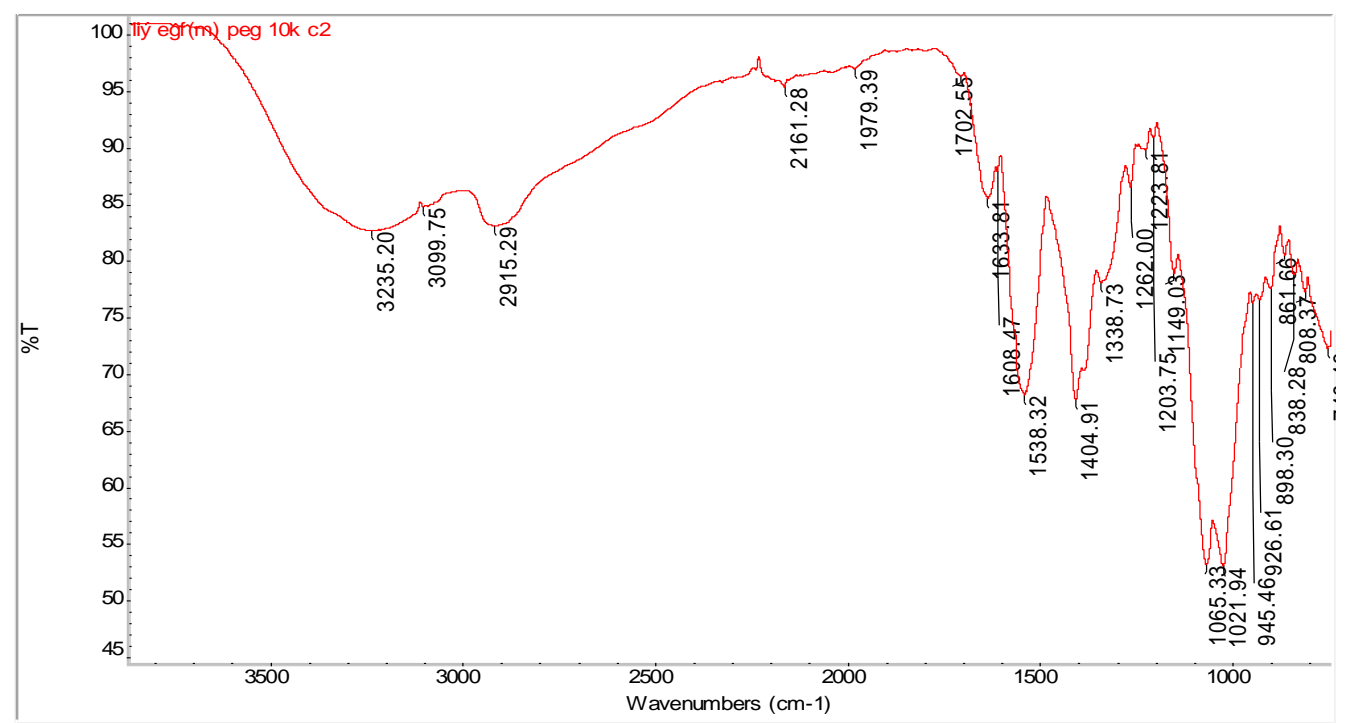

Figure 6: FTIR spectrum of $\mathrm{C} 2$ formulation with the characteristic signs. 


\section{Assessment of MTT cell viability results}

MTT cell viability results of hydrogels were shown in Figure 7. A formulation is accepted cytotoxic when the cell viability rate is under $70 \%{ }^{12}$. The cell viability results indicated that the formulations were safe for the cytotoxicity perspective on L-929 cell line. According to the results, there were substantial differences to the cytotoxicity results between the control group and rh-EGF free formulations containing only chitosan and PVA $(p<0.05)$. The cell viability rate of control (untreated) group was determined to be $100 \%$. MTT cell viability results showed that hydrogels including rh-EGF, rm-EGF and PEGylation agent performed a crucial contribution to cell viability. According to the MTT cytotoxicity results B1 $(94.20 \pm 1.30 \%)$ formulation showed the greatest L929 cell viability. F2 formulation $(93.20 \pm 2.35 \%)$ also showed high L-929 cell viability effect.

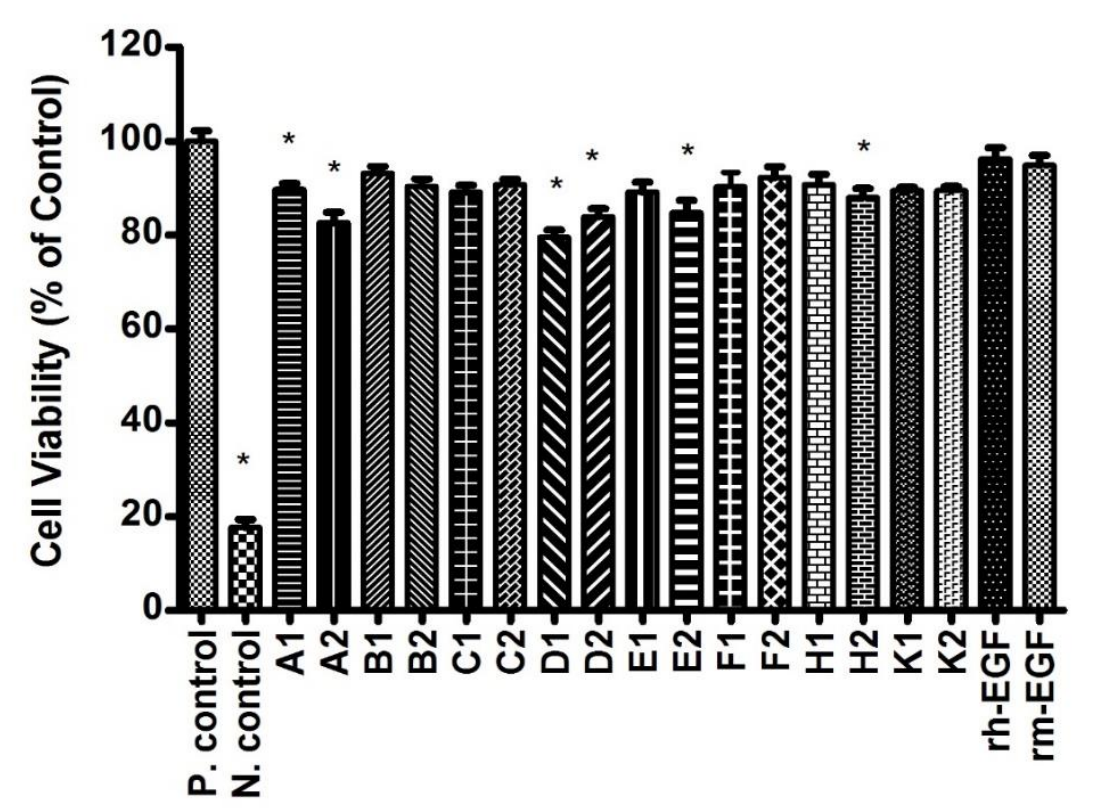

Samples

Figure 7: Cytotoxicity results of formulations in L-929 cell line. *Positive control group and negative control group were untreated. Positive control group included DMEM and L-929
cells, negative control group contained only DMEM.

The cytotoxicity study results showed that there were significant differences $(p<0.05)$ between control group (100\%) and compared to the hydrogel formulations such as D1 $(79.60 \pm 1.20 \%)$, D2 $(82.45 \pm 1.05 \%)$. According to the results, the absence of EGF and PEGylation agents in D1 and D2 formulations could be explained as the reason for having lower cell viability compared to the control group. The results showed that, cell viability of A1 formulation containing rh-EGF was $87.82 \pm 0.85 \%$ and A2 formulation containing rmEGF was $82.64 \pm 1.56 \%$. Results showed that B2 formulation including medium molecular weight chitosan and F2 formulation with high molecular weight chitosan had close cell viability results. It could be concluded from these results, the molecular weight of chitosan in the formulations did not make a significant difference in cell viability. Moreover, cell viability activity of rhEGF and rm-EGF were $95.30 \pm 1.30 \%$ and $93.80 \pm 0.95 \%$ respectively.

\section{CONCLUSION}

In this study, chitosan-PVA hydrogels were prepared and cytotoxicity of hydrogels was evaluated. Moreover, FTIR was used to indicate of specific chemical groups in the formulation and materials. Cytotoxicity results promoted the crucial effects of hydrogels on cell viability. According to the results, r-EGF types and PEGylation agents in 
hydrogels have been observed to increase cell viability. In conclusion, it can be said that chitosanPVA hydrogels including r-EGF types and PEGylation agents shed light on further cell viability studies.

\section{ACKNOWLEDGMENTS}

This study was supported by The Commission of Marmara University Scientific Research Project (BAPKO, SAG-C-DRP-131216-0537).

\section{REFERENCES}

1. Rana P, Ganarajan G, Kothiyal P. Review on preparation and properties hydrogel formulation. WJPPS. 2015; 4 (12): 10691087.

2. Pal K, Banthia AK, Majumdar DK. Polymeric Hydrogels: Characterization and Biomedical Applications. Des Monomers Polym. 2009; 12: 197-220.

3. Mohamed RR, Abu Elella MH, Sabaa MW. Synthesis, characterization and applications of N-quaternized chitosan/poly (vinyl alcohol) hydrogels. Int J Biol Macromol. 2015; 80: 149-161.

4. Vino AB, Ramasamy P, Shanmugam V, Shanmugam A. Extraction, characterization and in vitro antioxidative potential of chitosan and sulfated chitosan from Cuttlebone of Sepia aculeata Orbigny, 1848. Asian. Pac. J. Trop. Biomed. 2012; 2: 334-S341.

5. Mansur HS, Sadahira CM, Souza AN, Mansur AAP. FTIR spectroscopy characterization of poly (vinyl alcohol) hydrogel with different hydrolysis degree and chemically crosslinked with glutaraldehyde. Mater Sci Eng. 2008; 28: 539-548.
6. Dogan S, Demirer S, Kepenekci I, Erkek B, Kiziltay A, Hasirci N, et al. Epidermal growth factor-containing wound closure enhances wound healing in non-diabetic and diabetic rats. Int Wound J. 2009; 6: 107-115.

7. Hardwicke J, Schmaljohann D, Boyce D, Thomas D. Epidermal Growth Factor Therapy and Wound Healing - Past, Present and Future Perspectives. Surgeon. 2008; 6(3): 172-177.

8. Jevsevar S, Kunstelj M, Porekar VG. PEGylation of therapeutic proteins. Biotechnol. J. 2010; 5: 113-128.

9. Lee H, Jang IH, Ryu SH, Park TG. NTerminal Site-Specific Mono-PEGylation of Epidermal Growth Factor. Pharm Res. 2003; 20(5): 818-825.

10. Sezer AD, Cevher E, Hatipoğlu F, Oğurtan Z, Baş AL, Akbuğa J. Preparation of Fucoidan-Chitosan Hydrogel and Its Application as Burn Healing Accelerator on Rabbits. Biol Pharm Bull. 2008; 31(12): 2326-2333.

11. Arranja A, Schroder AP, Schmutz M, Waton G, Schosseler F, Mendes E. Cytotoxicity and internalization of Pluronic micelles stabilized by core crosslinking. J Control Release. 2014; 196:8795.

12. Wolf NB, Küchler S, Radowski MR, Blaschke T, Kramer KD, Weindi G, et al. Influences of opioids and nanoparticles on in vitro wound healing models. Eur $\mathbf{J}$ Pharm Biopharm. 2009; 73: 34-42.

13. Song $\mathrm{C}, \mathrm{Yu} \mathrm{H}$, Zhang M, Yang Y, Zhang G. Physicochemical properties and antioxidant activity of chitosan from the blowfly Chrysomya megacephala larvae. Int. J. Biol. Macromol. 2013; 60: 347-354. 